\title{
Polish Regional Elite Career Paths and the Impact of a Multilevel System
}

\author{
TATIANA MAJCHIERKIEWICZ
}

\section{Sciendo}

Politics in Central Europe (ISSN: 1801-3422)

Vol. 16, No. 1

DOI: $10.2478 /$ pce-2020-0013

\begin{abstract}
This paper aims to investigate the multilevel careers of members of Polish regional executives from the first direct election to regional parliaments in 1998 until the end of 2014. Formation of self-government in regions is assumed to have started the process of formation of the multilevel system in Poland. Consequently, political career paths began to be diversified and to take place at more than one level. Among the factors with a critical impact on the specificity of Polish regional careers was the fact that regionalisation was preceded by local government reform (1990), and it was assumed that the local elite would become its natural recruitment base. On the one hand, the challenge to the development of the multilevel system has to be recognised. First, regional politics has undergone rather limited professionalisation (only positions in regional executives are full-time political jobs). Second, the legacy of communist centralisation resulted in lukewarm regional decentralisation in 1998. However, one can observe a certain increased prominence of self-government due to access to EU funds and increased financial autonomy. Positions in regional executive boards, especially as heads of regional boards [marszałkowie], have been seen as increasingly attractive career choices for professional politicians. Therefore, modification of the traditional career model is expected, e.g. some inflow of national politicians into regional boards (from positions in the legislature to executive posts).
\end{abstract}

Key Words: Regional politicians - regional self-government - regional careers multilevel system -central government - local government 


\section{Introduction}

Numerous recent studies focusing on political careers in democratic and decentralised European countries show that career paths have been modified and diversified in multilevel settings as the institutional structure of opportunities has been transformed. Questions have been raised regarding the traditional 'political ladder', which assumed that politicians start their careers at a local level, ascend to the next step at a regional tier, before moving on to national politics (Borchert and Stoltz 2011a). This classic career pattern has become only one of the possible political trajectories. The individual ambitions affecting politicians' career choices vary, and have also been reshaped by the increased role of regional politics, especially as professionalisation of regional political positions has created an opportunity for full-time careers at that level. It is assumed that in Poland too, the formation of regional self-government in 1999 began the creation of a multilevel system, and thus it is expected that the political careers of regional politicians would also be diversified. The primary aim of the study, therefore, is to map this phenomenon: which institutions and which levels are the main recruitment base, and which are marginal in this process? Furthermore, 'post-ministerial' careers are investigated; which posts and which tiers have been attractive after occupying a post in Polish regional executives? Finally, the article examines the question of whether the politicians' careers are multilevel ones; on how many levels do they develop, and in which constellations?

This paper is divided into five parts. Part 1 presents regional government within the structure of the state. Part 2 is the methodological section. Part 3 presents a description of political and financial arrangements defining the performance of regional boards. The aim of this section is to provide the background information necessary to evaluate the availability and especially the attractiveness of political offices at the regional level, underlining their limited but increasing authority. Part 4, the main section, begins with an investigation of the movements between regional, national and European levels, followed by an analysis of movement between self-governing institutions: local and regional tiers. The last section of Part 5 focuses on the formation of a multilevel system in Poland. Although this is assumed to be at an early stage, and most members and heads of regional boards only move between two levels, it is important to define the scale of multilevel careers.

\section{Introduction: Regional government and the structure of the state}

Twenty years ago, on 1 January 1999, administrative reform in Poland led to the establishment of self-government at regional level. A new and potentially powerful regional elite - members of the regional boards (zarządy województwa), 
the Polish equivalent of regional government in other European countries came to power. Swianiewicz (2014: 356 and 375), referring to the introduction of regional self-government institutions, argues: 'They were created [...] as weak entities - with highly limited functions and even more scarce financial resources. Yet their importance in domestic politics grew significantly in the following years. [...] One may say that using the opportunities provided by EU structural funds, the Polish regions have grown (as political actors) from ugly ducklings to very strong and powerful swans'.

Thus, in analysing the career paths of members of the regional boards (approximately equivalent to regional ministers - although one should bear in mind the above comments on decentralisation), it is critical to remember that this was a period of radical shift in the prominence of the regional elite, and one might therefore expect there to have been an increase in the political attractiveness of regional careers. It is assumed that over time their careers would have evolved to the extent that the positions of heads of regional boards (marszałkowie - roughly equivalent to regional prime ministers) and other members of regional boards (wicemarszałkowie and czlonkowie zarzadu - roughly equivalent to regional ministers) would have started to be seen as attractive and sometimes alternative political careers.

The decentralisation in 1999 may be regarded as the starting point of the transformation of the Polish state towards a multilevel system. The territorial administration has since been split into regional and local. The latter is additionally subdivided into two tiers - communes (gminy) and districts (powiaty) - with no vertical subordination between them. Local government reform establishing communes was launched in 1990, but it took nine more years to conclude the self-government project, with districts and regions (or voivodeships (województwa)) being established in 1999. Polish regions were radically transformed, as 49 small units were merged into 16 regions (Map 1). It was assumed that this reform would overcome the communist legacy of centralisation and sectorial fragmentation, especially of economic management (Piasecki 2009: 183). However, regionalisation also aimed to improve the economic competitiveness of Polish regions in the European market. Polish regions, with their economic, political and social capacity expanded, were to become strong partners to their Western counterparts. The Polish administrative regions became European NUTS-2 level regions (Swianiewicz 2014: 359). 
Map 1: Polish regions (NUTS II regions)

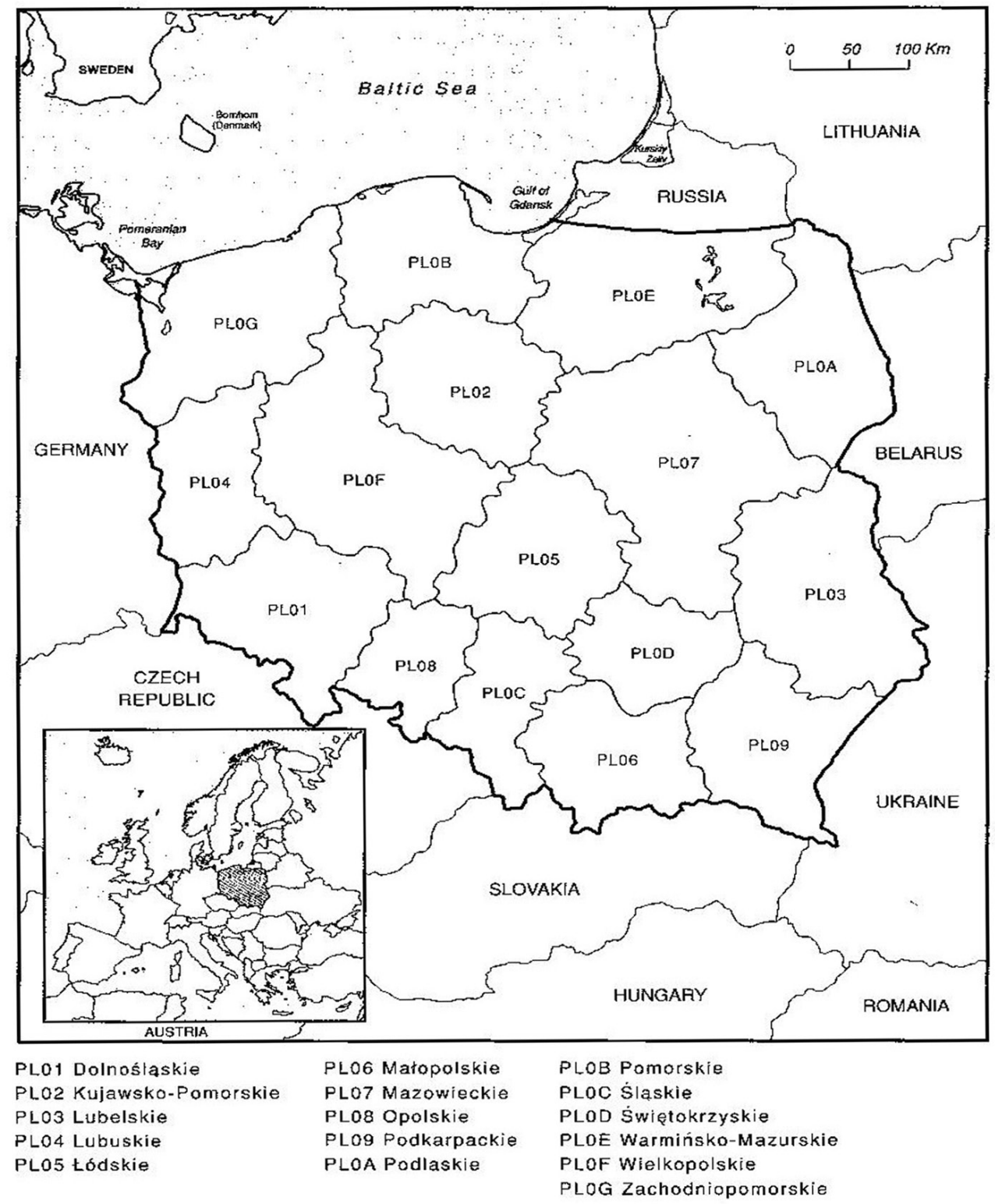

However, administrative reform did not completely eradicate previous institutional arrangements. As a result, since 1999 the Polish regions' new institutions of self-government have operated concurrently with the already existing central government, forming a dual administrative system. The central government is represented by a voivode (wojewoda), although the competencies of this position were substantially curtailed and the majority of his/her powers were transferred 
to regional self-government, composed of a regional assembly (sejmik) and its executive board (zarząd wojewódtwa), with the most prominent position being that of its head (marszałek województwa; this term is sometimes translated as marshal, but its connotations might be misleading), and also including four other members. Evaluating the political arrangements in regions and central-regional relations, Swianiewicz (2014) classifies Poland as a 'regionalised unitary state' (referring to Loughlin's [2001: 14] typology of states in the EU).

The main function of regional government is strategic planning and implementation of regional development programmes. In addition, it provides a limited number of services, including the construction and maintenance of regional roads and the organisation of regional transport. Regional government is also responsible for the maintenance of the health service infrastructure, which is a significant financial burden for regional budgets. These tasks of regional boards do not affect citizens directly, and consequently, recognisability of regional elites is rather low when compared to town mayors, for example (this should be noted as it may have an impact on the attractiveness of these posts). According to the Regional Authority Index, Poland is somewhere in the middle of the scale, with 8 points in total - 4 for Representation and 2 each for Institutional Scope and Policy Scope (Hooghe et al. 2010).

In modern Polish history, some regions have had regional self-government or autonomous status, but it must be stressed that this was the first time that self-government institutions were established in all 16 regions. ${ }^{1}$ Schakel and Dandoy (2013: 1), observing Western European regionalisation in the last 40 years, argue that: 'Not only has the authority exercised by regional governments increased, but the biggest driver of this growth of regional authority has been the proliferation of elected institutions at the regional level'. Thus, it is expected that these favourable conditions, at least in the long run, should lead to similar further decentralisation in Poland.

\section{Methodology}

The aim of this article is to examine Polish regional elite career paths and the impact of a multilevel system. Most recent studies on the political careers of regional politicians focus on Western European countries (Botella et al. 2010; Borchert 2011; Borchert and Stolz 2011a, b; Fischer and Stolz 2010; Stolz 2011; Stolz 2003; Stolz 2011; Stolz, Fischer 2014; Vanlangenakker et al. 2013; Jäckle 2013; Dodeigne 2018; Grimaldi and Vercesi 2018). In comparing the Polish

1 In the interwar period, regional government was established in only two of 17 regions (Poznań and Pomerania provinces). In addition, the Silesian region had autonomous status. Its regional parliament was equipped with law-making competencies and its own regional budget, permitting regional politicians to be the main decision makers in regional economic development policies (Ujdak 1996: 53 and Izdebski 1996: 147). 
case with its Western counterparts, it is worth stressing its distinctive feature, which is that although the state can be classified as a 'regionalised unitary state', decentralisation is still a very recent development and further regionalisation is required. Thus, in the case of movements between central and regional levels (whether centripetal or centrifugal), it is assumed that in the period under investigation this is still in the initial phase. In contrast to career models observed recently in Western Europe (Borchert and Stolz 2011), it is expected that in Poland the formation of regional self-government in 1999 did not so much modify the traditional, hierarchical model of political careers as create a new institutional structure in which the regional level was established and recognised. In other words, the hierarchical model assumes that experience in regional politics is a step towards national careers. However, serious doubts may be raised as to whether this role was performed by Polish regional politics prior to regional mergers. The existence until 1999 of 49 small regions substantially decreased the status of regional authorities (cf. Lewis 2009), thus limiting their chances of being a recruitment pool for national politicians. Applying Borchert's (2011) approach to the careers of Polish politicians, particular emphasis is placed on the issue of the attractiveness of regional careers, as it is assumed that their increased status is a precondition for the development of a multilevel system.

Furthermore, I argue, referring to opinions presented by heads of regional boards, that the formation of a fully-fledged multilevel system requires further regionalisation to the extent that its elite achieves sufficient authority permitting national political actors to begin to recognise regional politicians as partners and to overcome the still strongly entrenched tradition of centralisation. Nevertheless, as emphasised by heads of regional boards, in the last 20 years a substantial evolution has occurred, increasing the scope of decentralisation.

As mentioned above, the reform establishing regional self-government was preceded nine years earlier, in 1990, by local government reform. Thus, it is assumed that the local elite would have become the natural recruitment base for the new regional political strata. However, the inflow of local politicians is expected to have decreased since the 2002 local elections, when the direct election of mayors of towns and villages was introduced. I assume that this electoral reform substantially restrained movements between the local and regional levels, since candidates for mayoral positions prefer to present themselves during electoral campaigns as independents because being a party candidate in mayoral elections substantially decreases the chance of re-election (Drzonek 2016). ${ }^{2}$ On the contrary, in the case of promotion to the office of regional boards, membership of the state-wide party is one of the main preconditions. Furthermore, the

2 Since the communist period Poles have held rather negative attitudes towards political parties. The introduction of direct elections in 2002 therefore increased the tendency for 'local politicians' to distance themselves from political parties (statewide parties - SWP). 
movements between these two types of posts may also be hindered by the fact that mayors have been popular local leaders, whereas regional elite members have been much less recognisable by citizens.

The study investigates the political careers of regional elite members elected between 1998 and $2014^{3}$ (until the end of 2014 - including the newly elected regional politicians of the fifth term) ${ }^{4}$ In total this was 402 people, holding 647 positions on regional boards. ${ }^{5}$ Among them were 78 heads of regional boards, ${ }^{6}$ while 352 were members of regional boards (those elected to these functions before or after promotion to the office of the head, altogether 28 individuals, are added to this group ${ }^{7}$ ). The number of members of regional boards involved in movements from regions towards the centre (or local level) was 339, since this group did not include those who held these positions at the time of the research, ${ }^{8}$ and in the case of heads of regional boards their number was 62 (of 16 elected at the beginning of the fifth term, 14 were still in office). ${ }^{9}$

In addition, during 2014 and 2015, 59 unstructured interviews were conducted and voice-recorded in all 16 regions with heads of regional boards who held these positions from the first term to the beginning of the fifth (only 10 officeholders from 1999 till the end of 2014 refused to participate in the research). The interviews focused on their political career paths, but also on the role of political factors determining appointment to regional boards, especially the formation of regional coalitions and coordination of political bargaining with the centre (sometimes also with the local level). On average, the length of interviews with former heads of regional boards was between 1.5 and 2 hours (with the longest being 4.5 hours); for politicians in office, the interview time was on average 1 hour.

3 In the case of legislative offices, the research also includes those elected as MPs in the 2015 general election.

4 In 2018 the next regional election took place, but this is not covered by the article, which ends at the beginning of the fifth term, and is part of a wider research project on regional politics and politicians (forthcoming Majcherkiewicz 2020).

5 The positions of members of regional boards are formally divided into so-called deputy marshals (or deputies to the head - wicemarszatkowie) and 'members of the regional board' (członkowie zarzadu). However, in reality, this division does not indicate a different status between these positions. Accordingly, for the purpose of the calculations, they are treated as one group.

6 Among them, one politician only had the status of head of the regional board-elect (marszatek elekt) and his successor was a voivode and performed the functions of the head (osoba petniąca funkcje organów samorządu województwa podlaskiego) in the interim period until the early election.

7 Three people were heads of regional boards before and after holding other positions on regional boards.

8 Exceptions were made for those who, despite having held positions at the end of 2014, had post-ministerial careers due to the fact that they had a break in their tenure in work on regional boards.

9 In some cases, the division on a position held before and after being a member of regional boards becomes further complicated when politicians had a break in work in the regions, and in the meantime continued political careers at other levels (both first and second posts were taken as the reference point). 
The investigation incorporates both the movement from regions to the national centre - or, alternatively, to the local level - and in the opposite direction - from central and local tiers to voivodeships. In the regions, the research includes the political careers of both heads and members of regional boards. In relation to central offices, executive and legislative positions are included, as well as those of regional voivodes - representatives of the government administration in the regions. ${ }^{10}$ At the local level, the research embraces executive offices in the commune and district tiers. Finally, the analysis incorporates the European level, that is the position of MEPs. Furthermore, the scale of multilevel careers is evaluated.

In other words, the investigation covered in the article incorporates full-time political positions in self-governing institutions, but also the central government (and EU). It is argued that despite the formal autonomy of appointment to these institutions in a multilevel setting, movements between them are not only the result of individual choices. Rather, personnel policy in Poland is coordinated by political party multilevel strategies (which confirms direct moments ${ }^{11}$ - see especially the section on movement to and from positions of voivodes). The peak of these policies is assumed to have taken place during the Civic Platform (PO)/Polish People's Party (PSL) coalition government between 2007 and 2014, when these parties were cooperating in the centre and in the majority of regions (Majcherkiewicz 2018). This can be illustrated by the fact that agreement on the division of position of heads of regional boards within the PO-PSL coalition in 2010 was presented at a conference of the PO and PSL party leaders (who at the same time also held the positions of prime minister and deputy prime minister). ${ }^{12}$ Similarly, the interviewees representing these parties saw the interconnection of personnel policy in institutions controlled by these parties. One of the heads mentioned a more indirect impact: in ministries, there is a rule that if a cabinet minister represents the senior party, his/ her deputy will represent the junior party (and vice versa); a similar solution was also adopted for the positions of voivodes and their deputies. This way of thinking was then repeated in regional boards in a situation when one of the coalition partners (PO or PSL) could form one party board, although a second party was always invited to a regional executive.

10 They are formally classified as representatives of government - central administration. In reality, however, they seem to be representatives of regional administration. It is symbolic that in numerous cases, Offices of Regional Self-governments have been located in the same building as Voivodes' Offices.

11 Direct moments are those where there is no time gap between two political appointments (a politician has to resign from one position to move to others).

12 First agreement of 2010 and second of 2014 (Tusk: jest porozumienie PO-PSL o koalicji w sejmikach, [25. 11. 2015] https://wiadomosci.wp.pl/tusk-jest-porozumienie-po-psl-o-koalicji-w-sejmikach6082117185360513a, and Koalicja PO-PSL będzie rządzić w 15 sejmikach wojewódzkich https://www.tvn24. pl/wiadomosci-z-kraju,3/koalicja-po-psl-bedzie-rzadzic-w-15-sejmikach-wojewodzkich,492507.html. 
Table 1: Movements within regional executive boards

\begin{tabular}{|l|c|l|}
\hline Positions & $\begin{array}{l}\text { Before promotion to the office of } \\
\text { head of regional board }\end{array}$ & $\begin{array}{l}\text { After promotion to the office of } \\
\text { head of regional board }\end{array}$ \\
\hline Members of regional boards & $26.9 \%(21)$ & $12.8 \%(10)$ \\
\hline
\end{tabular}

\section{Regional government: political arrangements, regional authority and financial decentralisation}

Elections to the regional assembly took place in all 16 regions at the same time every four years (see Table 2). Members of the regional boards have traditionally been chosen from regional deputies. In the case of positions as heads of regional executive bodies, in the 1998-2001 period, they had to be elected from regional deputies, although currently this requirement has been withdrawn, and they have usually been chosen from those sitting in regional assemblies. Comparing Polish deputies with their Western counterparts, it should be stressed that in the former case it is not a full-time job. Polish assemblies meet occasionally (usually once a month). Among their competencies are the enactment of regional development strategies and approval of a yearly budget, and the regional executive has to receive an annual vote of approval on implementation of the regional budget. ${ }^{13} 14$

\section{Table 2: Dates of regional elections and terms of office}

\begin{tabular}{|l|l|}
\hline Dates of regional elections & Terms of office \\
\hline 11 Oct. $1998^{13}$ & Term I (1998-2002) \\
\hline 27 Oct. 2002 & Term II (2002-2006) \\
\hline $\begin{array}{l}\text { 12 Nov. } 2006-20 \text { May } 2007 \text { early election in } \\
\text { Podlasie region } 14\end{array}$ & Term III (2006-2010) \\
\hline 21 Nov. 2010 & Term IV (2010-2014) \\
\hline 16 Nov. 2014 & Term V (2014-2018) \\
\hline 21 Oct 2018 & $\begin{array}{l}\text { Term VI (2018-2013 [term in office extended to } \\
\text { five years] }\end{array}$ \\
\hline
\end{tabular}

\footnotetext{
13 Elections took place three months before the regional government institutions came into operation, as this gave regional assemblies time to choose their executive board.

14 In the Podlasie region in the aftermath of the regular 2006 election, the regional assembly was unable to select the executive board in the required timespan.
} 
In financial terms, the positions of heads of regional boards are rather attractive. Their salaries are comparable to those of national MPs and higher than those of junior ministers. In total, 80 offices in regional executives may be regarded as full-time political positions (as offices in regional assemblies are only semi-professionalised). The number of political offices at the regional level is therefore smaller than that at the national level (Borchert 2011; Stolz 2005) $\cdot{ }^{15}$ Defining the political authority of the regional elite and the attractiveness of the offices of heads and members of regional boards, it is critical to determine the extent of decentralisation of finances. In the Regional Authority Index mentioned above, Polish regions received 0 points for fiscal autonomy. Table 3 shows that the regionalisation of 1999 was assisted only by restricted financial decentralisation. In the period under investigation, the share of regions in sub-national budget spending rose from just over $5 \%$ to less than $9 \%$ in 2012 . The central government preserved its privileged position, but the regional budget share was low compared to the local government budget (municipalities and especially major cities [those with district status]) (Swianiewicz 2014: 358).

\section{Table 3: Revenue and proportion of expenditure in revenues in local and} regional self-government (in billion PLN)

\begin{tabular}{|l|c|c|c|c|c|c|c|c|c|c|}
\hline Type/year & $\mathbf{2 0 0 4}$ & $\mathbf{2 0 0 5}$ & $\mathbf{2 0 0 6}$ & $\mathbf{2 0 0 7}$ & $\mathbf{2 0 0 8}$ & $\mathbf{2 0 0 9}$ & $\mathbf{2 0 1 0}$ & $\mathbf{2 0 1 1}$ & $\mathbf{2 0 1 2}$ & $\mathbf{2 0 1 3}$ \\
\hline $\begin{array}{l}\text { Income of } \\
\text { communes }\end{array}$ & 33.9 & 45.5 & 51.4 & 56.6 & 62.6 & 64.8 & 72.2 & 75.7 & 78.3 & 79.9 \\
\hline $\begin{array}{l}\text { Incomes of districts } \\
\text { cities (those with } \\
\text { district status) }\end{array}$ & 12.3 & 13.6 & 14.6 & 16.0 & 18.3 & 20.1 & 22.5 & 23.5 & 22.5 & 23.1 \\
\hline $\begin{array}{l}\text { Incomes of regions } \\
\text { Incomes of major }\end{array}$ & 6.9 & 7.0 & 9.4 & 11.3 & 12.8 & 19.6 & 14.1 & 15.1 & 15.2 & 16.1 \\
\hline $\begin{array}{l}\text { Total incomes of self- } \\
\text { government }\end{array}$ & 90.1 & 101.7 & 115.5 & 129.8 & 143.6 & 155.0 & 162.8 & 171.2 & 177.4 & 183.2 \\
\hline
\end{tabular}

Source: Trochymiak (2017: 182)

15 The number of political positions is formally smaller at the regional level, but as the interviews with heads of regional boards indicate, the positions of directors of departments in regional government office are treated as spoils. In addition, the civil service corps exists only in the central administration; no similar reform has been undertaken in self-government administration. In other words, there is no clear division between political and administrative posts. 
Interviews conducted with heads of regional boards showed that they regarded the main challenge limiting the authority of the regional executive to be the preservation of strict financial control by the national government. Although several tasks were transferred to regions, the central authority financed them in the form of grants from the central budget, and specific rather than general purpose transfers dominated (cf. Bober et al. 2013: 46-48). Thus, heads of regional boards strongly advocated the necessity of what they called 'financial decentralisation'. Statistical data for 2014 indicates that regions received most of the revenue in the form of subsidies, whereas their own regional revenue comprised only $36.9 \%(6,546,100$ PLN out of a total 17,745,600 PLN) (Błażej, 2015: 113-4). However, referring to the multilevel system, the impact of EU enlargement has to be recognised. For example, in 2014 regions received the largest share of financial resources for EU projects implemented by self-government (36.3\% - 6,600,600 PLN) (compared with local government (municipalities, cities with district status and districts)) (Błażej, 2015: 40). In other words, although it is essential for deepening regional democratisation that regional authorities gain more autonomy over regional finances, at the same time one has to recognise two facts: first, progress made over time, and second, the critical importance of EU enlargement.

\section{Multilevel-movements}

\section{Central-regional level movements}

In analysing movements between political offices at the central and regional levels, the first striking feature is their disproportional intensity in some categories. In more than $20 \%$ of cases they had political experience of being a voivode or deputy prior to appointment as the head of a regional board; all other central-level categories were much less important sources of cadres for the regional executive.

In the case of post-ministerial careers, the most popular option - a parliamentary career - was chosen by nearly one third of heads of regional boards. The movement to the national legislature was also the most popular among all members of the regional boards, at over $20 \%$.

At the same time, some central-regional positions can be seen as not incorporated in these multilevel movements. For example, heads of regional boards were rarely promoted to the positions of ministers (both cabinet and junior ministers).

Secondly, it could be argued that heads of regional boards have more distinguished careers than other members of regional executives in two ways. In some categories, they vary in intensity, with heads of regional boards having a more favourable opportunity for certain career options at the central level, 
Table 4: Movements from the centre towards regions

\begin{tabular}{|c|c|c|c|c|c|}
\hline \multicolumn{2}{|l|}{ Positions } & \multicolumn{2}{|c|}{$\begin{array}{l}\text { Heads of regional } \\
\text { boards }\end{array}$} & \multicolumn{2}{|c|}{$\begin{array}{l}\text { All members of the } \\
\text { regional boards }\end{array}$} \\
\hline \multirow[t]{3}{*}{$\begin{array}{l}\text { National } \\
\text { parliament }\end{array}$} & Parliament - both chambers & $11.53(9)$ & \multirow{7}{*}{$\begin{array}{c}16.67 \\
(13)\end{array}$} & $8.96(36)$ & \multirow{7}{*}{$\begin{array}{l}10.45 \\
(42)\end{array}$} \\
\hline & Lower chamber & $6.41(5)$ & & $6.72(27)$ & \\
\hline & Upper chamber & $6.41(5)$ & & $2.49(10)$ & \\
\hline \multirow[t]{4}{*}{$\begin{array}{l}\text { National } \\
\text { Executive }\end{array}$} & Offices in national executive & $7.69(6)$ & & $2.24(9)$ & \\
\hline & Prime minister & $0(0)$ & & $0(0)$ & \\
\hline & Cabinet minister & $2.56(2)$ & & $0.75(3)$ & \\
\hline & Junior minister & $5.12(4)$ & & $1.74(7)$ & \\
\hline \multirow{3}{*}{$\begin{array}{l}\text { Representatives } \\
\text { of central } \\
\text { government } \\
\text { in regions }\end{array}$} & Voivodes and their deputies & \multicolumn{2}{|c|}{$20.51(16)$} & \multicolumn{2}{|c|}{$12.19(49)$} \\
\hline & Voivodes & \multicolumn{2}{|c|}{$10.25(8)$} & \multicolumn{2}{|c|}{$4.48(18)$} \\
\hline & Deputy voivodes & \multicolumn{2}{|c|}{$10.25(8)$} & \multicolumn{2}{|c|}{$7.96(32)$} \\
\hline \multicolumn{2}{|c|}{ TOTAL - ALL POSITIONS AT CENTRAL LEVEL } & \multicolumn{2}{|c|}{$34.62(27)$} & \multicolumn{2}{|c|}{$21.64(87)$} \\
\hline \multicolumn{2}{|l|}{$(n)$} & \multicolumn{2}{|c|}{$100(78)$} & \multicolumn{2}{|c|}{$100(402)$} \\
\hline
\end{tabular}

Comments: The values in the table do not sum up. The movements of one person can be inserted in more than one cell, where when he/she holds more than one central-level position. For example, a head of a regional board may have experience as a member of parliament (lower chamber) as well as senator, thus a supplementary cell for both chambers was added as well as the total number of all central-level positions.

and thus they represent a more intense inflow. Furthermore, in other categories heads of regional boards vary from other members of regional executive not so much in the intensity of their inflow, but in the type of positions they choose for their post-ministerial career. One might argue that some political career paths are neither as attractive nor as available for these two groups. In order to discern trends, therefore, the analysis is divided into three categories related to the type of positions: national executive, central legislature and offices of regional voivodes and their deputies - representatives of the central government in regions. 
Table 5: Movements from regions towards the centre

\begin{tabular}{|c|c|c|c|c|c|}
\hline \multicolumn{2}{|l|}{ Positions } & \multicolumn{2}{|c|}{$\begin{array}{c}\text { Heads of regional } \\
\text { boards }\end{array}$} & \multicolumn{2}{|c|}{$\begin{array}{l}\text { All members of the } \\
\text { regional boards }\end{array}$} \\
\hline \multirow[t]{3}{*}{$\begin{array}{l}\text { National } \\
\text { parliament }\end{array}$} & Parliament - both chambers & $\begin{array}{c}30.65 \\
(19)\end{array}$ & \multirow{7}{*}{$\begin{array}{c}32.26 \\
(20)\end{array}$} & $\begin{array}{c}20.35 \\
(69)\end{array}$ & \multirow{7}{*}{$\begin{array}{c}23.01 \\
(78)\end{array}$} \\
\hline & Lower chamber & $25.81(16)$ & & $17.7(60)$ & \\
\hline & Upper chamber & $8.06(5)$ & & $3.54(12)$ & \\
\hline \multirow[t]{4}{*}{$\begin{array}{l}\text { National } \\
\text { executive }\end{array}$} & Offices in national executive & $4.83(3)$ & & $7.08(24)$ & \\
\hline & Prime minister & $0(0)$ & & $0(0)$ & \\
\hline & Cabinet minister & $0(0)$ & & $1.18(4)$ & \\
\hline & Junior minister & $4.83(3)$ & & $6.49(22)$ & \\
\hline \multirow{3}{*}{$\begin{array}{l}\text { Representatives } \\
\text { of central } \\
\text { government in } \\
\text { regions }\end{array}$} & Voivodes and their deputies & \multicolumn{2}{|c|}{$3.22(2)$} & \multicolumn{2}{|c|}{$4.13(14)$} \\
\hline & Voivodes & \multicolumn{2}{|c|}{$1.61(1)$} & \multicolumn{2}{|c|}{$2.06(7)$} \\
\hline & Deputy voivodes & \multicolumn{2}{|c|}{$1.61(1)$} & \multicolumn{2}{|c|}{$2.06(7)$} \\
\hline \multicolumn{2}{|c|}{ TOTAL - ALL POSITIONS AT CENTRAL LEVEL } & \multicolumn{2}{|c|}{$33.87(21)$} & \multicolumn{2}{|c|}{$25.66(87)$} \\
\hline \multicolumn{2}{|l|}{ (n) } & \multicolumn{2}{|c|}{$100(62)$} & \multicolumn{2}{|c|}{100 (339) } \\
\hline
\end{tabular}

Comment: The values in the table do not sum up.

\section{The national executive}

Investigation of the movements to and from national executive offices to the regional level will be conducted in three stages.

In the first stage it will focus on the movement to and from top positions of cabinet ministers. None of the heads of regional boards (in office during the period of investigation) was promoted to a position of national minister (or prime minister). Movement in the opposite direction was quite low $-2.6 \%$. Two former cabinet ministers became heads of regional boards, and another a regional board member. The number is so low that these cases are analysed together. All these appointments took place before 2006. One head of a regional board was a minister during the communist era. The two other offices in the regional executive should be treated as interim positions, as former national 
ministers resigned from them after being re-elected as MPs. The low centrifugal ratio was expected, even in federal states, e.g. in Germany former federal ministers very rarely decide to continue their careers at the regional level (Fischer and Stolz 2010: 14). However, compared with Poland's Western counterparts, it is puzzling that none of the 78 heads of regional boards became a cabinet minister. If observations were concluded at this stage, one could seriously question the formation of a multilevel system in the country. However, this pattern is modified if one includes the positions of junior ministers.

The second stage is therefore movements to and from the position of junior ministers (sekretarz i podsekretarz stanu) to heads of regional boards. Movements between these two positions are more common: $5.1 \%$ for movements from the centre towards regions and $4.8 \%$ in the opposite direction. However, it is worth investigating centrifugal movements in more detail. Four former junior ministers became heads of regional boards: one was elected in 2002, and the other three in the fourth term, and to move into a regional career all of them first had to resign from offices held at the central level. ${ }^{16}$ This suggests that recently, for some former junior ministers (and some parliamentarians - see next section) as well as for national party leadership coordinating personnel policies, positions as heads of regional boards have begun to be seen as attractive. Analysis at this stage suggests that multilevel careers have started to evolve, but this is still at an early stage.

In the third stage, after extending analyses on all members of the regional executive, one more trend appears. The centrifugal direction of movements between the national executive (both ministers and their deputies) and regional boards positions is very low $-2.2 \%$. At the same time, former members of regional boards relatively often choose the career option of moving to positions of deputy ministers and ministers. This is nearly three times more common (7.1\%) than in the opposite direction (see details in Tables 3 and 4). In addition, it is worth emphasising that movement from regional executive positions to offices of national deputy ministers is slightly more popular among members of the regional executive than their heads (probably also because this is more attractive in financial terms than the second category). There is one more difference between movements from regions towards the centre for heads of regional boards and other regional politicians, as four representatives of the latter category became national ministers (and one national deputy also became prime minister) but no heads of regional boards were appointed to such posts (although among all members of the regional boards this type of career was very rare, at $1.2 \%$ ). Finally, career patterns at this stage suggest a hierarchical model.

16 Two people resigned from positions as junior ministers and one person was a former junior minister, but was a senator at the time he received an offer to become the head of a regional board. 
Analysing movements in this category, high intensity is noticeable in both directions, to and from the national legislature. Nearly $9 \%$ of former MPs moved to positions in regional boards, and more than $11 \%$ became heads of regional boards. Movements in the opposite direction have been significantly higher - nearly three times as high in the case of heads of regional boards and twice as high among all members of regional boards. This direction of movements indicates the classic hierarchical model of careers. Furthermore, in these regional post-ministerial careers, movements to the lower (more powerful) chamber are dominant. ${ }^{17}$

\section{Offices of voivodes and their deputies}

An issue that has to be taken into consideration when analysing movement to and from the position of voivodes and their deputies is that they have been representatives of the central government, and appointments depend on this. In the multilevel setting, however, when the same party rules both centrally and in a region, their personnel policy includes coordination of both central government and regional self-government positions. It could be argued that the closed interconnection between these two types of institutions can be seen directly after the 2001 parliamentary elections, when six members of regional boards resigned to take the positions of voivodes (representative of the central government) or their deputies. An excellent illustration of this phenomenon is the policy of the PSL, characterised by mostly direct movements between both institutions despite the argument raised above, which might be expected to be an obstacle. ${ }^{18}$ The extent of this coordination is illustrated by the career of

17 An indicator which may show a potential rise of attractiveness of regional-level offices towards the centre is changes in direct movement to and from regions. The first type of direct movement from regions to the centre was intensive at the beginning; in the first term following the 2001 parliamentary election, three heads of regional boards resigned from the office to be promoted to the position of MP. This phenomenon did not appear for the next 14 years. This seems to suggest that regional careers began to be an attractive career alternative. However, this interpretation at least partially contradicts the fact that after the general election in 2015 two heads of regional boards resigned, instead choosing parliamentary careers. Movement in the opposite direction was much more even: in both the first and the second terms, one parliamentarian resigned to take up a position as the head of a regional board. In the fourth term there were two such cases, and in the fifth term one person. However, there is one interesting detail which suggests that the positions of heads of regional boards are gaining a certain prominence. The two direct movements which took place in the fourth term did not occur after the election, but in the middle of that period, as they were urgent replacements for the posts of heads of the regional boards in situations of political crises. Political parties chose as their representatives politicians whom the central structure of the party and its leaders trusted; national deputies who were induced to resign from their positions in order to take up posts as heads of regional boards.

18 The fact that this policy was mastered not by the main political party can probably be interpreted as meaning that it only has a limited pool of available professional politicians. 
one politician from the Wielkopolska region; after the first regional election in autumn 1998 he resigned from the position of deputy voivode to take up a post in the regional board, and directly after the parliamentary election in 2001, when the PSL became a junior coalition partner, he resigned from work in self-government to again become a deputy voivode, a position in which he remained until 2003. In 2006 he again became a member of the regional board, and he still holds this position today. ${ }^{19}$ Furthermore, one could argue that in the period from 2007 to 2014 coordination of political appointments was conducted within the PO-PSL coalition (which existed in the centre and in the regions; Majcherkiewicz 2016). Referring to the situation after the 2007 parliamentary election, Machelski (2008: 234) suggests the agreement of its leaders encompassing both types of positions: 'Your voivode and our head of regional boards', which means that in regions where the first position was held by the junior partner (PSL), the second would go to the senior one (PO).

Movements to and from voivode positions are in the opposite direction to national parliamentary posts, with movements in the centrifugal direction dominating, at $12.2 \%$, compared to those from regions towards the centre, at 4.1\%. This reflects a shift in authority between these two 'regional' centres of political power, with a decrease in the scope of authority of voivodes (although they are formally defined as representatives of the central government). Therefore, some of the interviewed heads of the regional boards emphasised that their movement from a position of voivode to a position in self-government was their individual career choice.

Furthermore, it is important to remember that after the mergers of territories in 1999 (reducing the number of regions from 49 to 16), a large number of regional politicians became unemployed, forming a recruitment base for regional executives. A substantial number (20) of the heads and members of regional boards who prior to their appointment held positions as voivodes or deputies 49 individuals altogether - were appointed in the first term (1998-2002). ${ }^{20}$ Former voivodes and their deputies were also reappointed in successive terms. However, the watershed was the regional election of 2014, after which none of the former voivodes or their deputies were promoted to positions of heads of regional boards. Concerning movement from positions of head of regional boards to voivodes, there was only one such case in $2011-1.6 \%$.

19 This was not the only case of shifts between those institutions; one person was a voivode in the gap between holding positions in the regional boards, and the other was a voivode before and after holding the position of head of a regional board.

20 The number of voivodes in the first term may be slightly underestimated (as data for the 1989-1999 period, when 49 regions existed, is incomplete). 


\section{European-regional level movements}

In the case of movements between regional and European levels, as the first election to the European Parliament in Poland only took place in 2004, the impact of this level was expected to be rather modest. None of the heads of regional boards had experience being MEPs before being promoted to this position.

Table 6: Movements from the European level to regions

\begin{tabular}{|l|c|c|}
\hline Positions & Heads of regional boards & All members of regional boards \\
\hline European Parliament & $0(0)$ & $0.5(2)$ \\
\hline (n) & $100(78)$ & $100(402)$ \\
\hline
\end{tabular}

However, six heads of regional executives (9.6\%) chose this type of career afterwards. This career option seems to be more available in the initial period of regional self-government, as there were 4 cases among those ruling in the first term.

It is interesting to note that if the calculations of movements from regions towards national and European levels are analysed together, among heads of regional boards this is the second most popular choice after parliamentary careers. Notwithstanding, movements towards this level were rather insignificant in the case of members of regional boards.

Table 7: Movements from regions to the European level

\begin{tabular}{|l|c|c|}
\hline Positions & Heads of regional boards & All members of regional boards \\
\hline European Parliament & $9.6(6)$ & $2.9(10)$ \\
\hline (n) & $100(62)$ & $100(339)$ \\
\hline
\end{tabular}

\section{Local-regional level movements}

The data gathered confirms that local government politicians were an important recruitment base for the regional elite. More than $42 \%$ of heads of regional boards and more than $28 \%$ of members of regional boards worked in local positions in communes. However, the proportion of popular local leaders (mayors of the main cities) is quite low: 6.4\% among heads of regional boards and $3.2 \%$ among other regional politicians. The most recent occasion when 
a former mayor of a main city was appointed as head of a regional board was in 2008. In other words, although the local elite is the main recruitment base for regional politics, this path is not seen as an attractive career option for local leaders of main cities - directly elected mayors. Furthermore, only $2 \%$ of former regional elite members became mayors of the largest cities. Nevertheless, they were already appointed after the introduction of direct elections of town mayors (pointing to the increased importance of SWP at the local levels in 2010 and 2014).

\section{Table 8: Movements from local level to regions}

\begin{tabular}{|c|c|c|c|}
\hline \multicolumn{2}{|r|}{ Positions } & Heads of regional & All members of \\
\hline \multirow{2}{*}{ Communes } & $\begin{array}{l}\text { Executive office in communes (mayors } \\
\text { and their deputies) }\end{array}$ & $42.31(33)$ & $28.61(115)$ \\
\hline & $\begin{array}{l}\text { Mayors of the largest cities (with district } \\
\text { status) }\end{array}$ & $6.41(5)$ & $3.23(13)$ \\
\hline \multirow[t]{2}{*}{ Districts } & $\begin{array}{l}\text { Executive offices on district executive } \\
\text { boards (heads of executive boards and } \\
\text { their deputies) }\end{array}$ & $6.41(5)$ & $7.71(31)$ \\
\hline & Heads of executive boards & $5.13(4)$ & $3.98(16)$ \\
\hline \multicolumn{2}{|c|}{ TOTAL - ALL POSITIONS AT LOCAL LEVEL } & $43.59(34)$ & $33.58(135)$ \\
\hline$(\mathrm{N})$ & & $100(78)$ & $100(402)$ \\
\hline
\end{tabular}

Comment: The values in the table do not sum up.

A much lower inflow of cadres took place from districts. In the case of heads of regional boards, nearly all politicians promoted from that level were heads of executive boards (starostowie). The source of this limited movement between regional and district levels is probably related to the small scope of competencies transferred to districts. This movement is especially low for the direction of regions to districts $-2.3 \%$. This low intensity of inflow to and from districts accompanied by more accelerated movement from communes to voivodeships can be recognised as adaptation of Polish politicians to the low attractiveness of district positions and, paradoxically, as an argument supporting formation of a multilevel system. Finally, out of 135 who moved from a commune or district to regions, 23 returned again to the local level after a short regional career (the overwhelming majority worked again in the same community or district). 
Table 9: Movements from regions to local level

\begin{tabular}{|c|c|c|c|}
\hline \multicolumn{2}{|r|}{ Positions } & Heads of regional & All members of \\
\hline \multirow{2}{*}{ Communes } & $\begin{array}{l}\text { Executive office in communes (mayors } \\
\text { and their deputies) }\end{array}$ & $6.45(4)$ & $11.5(39)$ \\
\hline & $\begin{array}{l}\text { Mayors of the largest cities (with district } \\
\text { status) }\end{array}$ & $1.61(1)$ & $2.06(7)$ \\
\hline \multirow[t]{2}{*}{ Districts } & $\begin{array}{l}\text { Executive offices on district executive } \\
\text { boards (heads of executive boards and } \\
\text { their deputies) }\end{array}$ & $1.61(1)$ & $2.36(8)$ \\
\hline & Heads of executive boards & $0.0(0)$ & $0.88(3)$ \\
\hline \multicolumn{2}{|c|}{ TOTAL - ALL POSITIONS AT LOCAL LEVEL } & $8.06(5)$ & $13.57(46)$ \\
\hline$(\mathrm{N})$ & & $100(62)$ & $100(339)$ \\
\hline
\end{tabular}

Comment: The values in the table do not sum up.

To conclude, in addition to the fact that the local level is the main recruitment base for the regional elite, the second crucial thing to note is that when analysing movements between different local tiers (communes and districts) and regions, centrifugal movements are more frequent than in the other direction. This suggests that for some politicians a hierarchical model of careers in Poland is still an attractive option. However, it is important to recognise the group of local politicians with interim work in regional self-government.

\section{The movement towards multilevel careers}

Taking into consideration the fact that Polish self-government has been in existence for only two decades, the formation of a multilevel system is a rather new phenomenon. Thus, in contrast to Botella et al. (2010), for example, focusing on the experience of regional prime ministers preceding their appointment, in the case of Polish politicians, their career before and after sitting on regional boards is investigated. Furthermore, seven levels were distinguished, adapting to the specific characteristics of the Polish political system: 1. local, type 1 - commune; 2 . local, type 2 - district; 3 . regional, type 1 - being a member of a regional board; 4 . regional, type 2 - positions of the heads of regional boards; 5. central, type 1 - deputies of national parliament or ministers; 6 . central, type 2 - positions of voivodes (and their deputies); and 7. European (MEP). Local, regional and central levels were divided into two. If a regional politician held positions at the commune and district level they were counted separately as two. 
At the regional level, the decision to divide it into two categories was intended to enable a distinction between those heads of regional boards who before or after holding these positions were also members of regional executives and those who did not have such experience. In relation to the central tier, since the positions of voivodes can be seen as quite distinct from other types of central offices, this level was also subdivided into two.

Table 10: Type of careers of regional prime ministers and ministers

\begin{tabular}{|c|c|c|}
\hline & \multicolumn{2}{|c|}{ Multilevel careers } \\
\hline Type of career & $\begin{array}{l}\text { Heads of } \\
\text { regional boards }\end{array}$ & $\begin{array}{l}\text { All members of } \\
\text { regional boards }\end{array}$ \\
\hline One level & $12.82(10)$ & 36.57 (147) \\
\hline 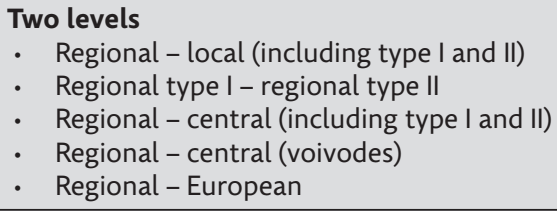 & $\begin{array}{l}37.18(29) \\
11.54(9) \\
5.13(4) \\
19.23(15) \\
8.97(7) \\
1.28(1)\end{array}$ & $\begin{array}{l}39.80(160) \\
20.90(84) \\
1.00(4) \\
17.66(71) \\
6.72(27) \\
0.25(1)\end{array}$ \\
\hline $\begin{array}{ll}\text { Multilevel } \\
\text { - } & \text { Three levels } \\
\text { - } & \text { Four levels } \\
\text { - } & \text { Five levels }\end{array}$ & $\begin{array}{c}\mathbf{5 0 . 0 0 ( 3 9 )} \\
33.33(26) \\
12.82(10) \\
3.85(3)\end{array}$ & $\begin{array}{c}23.63(95) \\
18.66(75) \\
4.23(17) \\
0.75(3)\end{array}$ \\
\hline (n) & 78 & 402 \\
\hline
\end{tabular}

More than $12 \%$ of heads of regional boards had single-level careers, over $37 \%$ worked in two-level careers, and half had multilevel ones. If one looks at all members of the regional boards, multilevel careers are strikingly less popular (nearly one quarter). Single- and two-level careers are similarly popular among them. For this category, it is not so much the limited range of multilevel careers that is surprising but the fact that the proportion of single-level careers is so high. To some extent, this low proportion of members of regional boards (and their members) with experience at more than two levels can be explained, as mentioned above, by the fact that regional self-government in Poland is only 20 years old. However, two more arguments may also be considered. First, the role of regional politicians has increased, but this has to be seen as a process which requires time, and centralisation tendencies have an impact on the pace of its development. Second, even if the multilevel system is less evident in the number of tiers, the example of trajectories of two-level careers shows its rising diversification, which is typical of the multilevel system. 


\section{Conclusion}

The data gathered indicates that the careers of regional politicians evolve towards a multilevel system. Although a large number of regional politicians have had experience of only one level (nearly 37\%), it is important to underline that the majority of careers are already highly diversified - a variety of types of two-level careers. Furthermore, already a quarter of all members of regional boards had worked at least three levels. Among heads, this proportion rises to even $50 \%$, which suggests that in the case of this group of politicians the process of evolution towards multilevel careers is clearly more advanced. Although some movements suggest an evolution towards a hierarchical model of careers in Poland, this is only one of the possible paths, as career trajectories are highly differentiated. Interviews with the heads of regional boards suggest that the attractiveness of political posts has been changing, and it is worth stressing that for some politicians, executive jobs at the lower level are more attractive than those in the legislature at the national level.

Movements between local and regional levels to a large extent confirmed expectations concerning the career paths of regional politicians. First, at the local level, as assumed, communes became a recruitment base for heads and members of regional boards. One third of them were members of local executives (mostly communes and occasionally districts) prior to being appointed. At the same time, the low proportion of former mayors of the main cities among the regional elite is striking, although it was expected that the introduction of direct elections to the position of mayor in 2002 would hinder movements between the local and regional levels. Furthermore, inflow between local and regional institutions suggests evolution towards a hierarchical model, although for some local politicians work in a region was a short break in their career in a commune (or in rare cases in districts).

Secondly, even more complicated and ambiguous career paths appeared when analysing movements between the central and regional levels. This was only partially surprising, however, as in a multilevel system diversification of political career was expected. Movements between certain categories support the argument for the appearance of a hierarchical model (e.g. to and from the national parliament, additionally higher intensity of movement from the local level to regions than in the opposite direction). The lack of movements in other categories suggests not only the absence of hierarchical careers but that that development of a multilevel is in the early stages (to and from the positions of national ministers) ${ }^{21}$ In addition, there are examples of national political

21 Although the research does not extend to autumn 2019 it is worth noting symptoms of the change to this trend. In Mateusz Morawiecki's first government in autumn 2019, among its 21 members there were already two former members of regional boards (Skład Rady Ministrów, Biuletyn Informacji Publicznej, https://bip.kprm.gov.pl/kpr/bip-rady-ministrow/sklad-rady-ministrow/4574,Sklad-Rady-Ministrow.html). 
careers (in this case posts of deputy ministers) whose attractiveness seems to vary according to positions in regional boards; they seem to be less attractive for heads of regional boards.

The main conclusion, therefore, is that although the traditional model has been a rather popular route, political career paths have been transforming and the impact of a multilevel system is noticeable in various areas. This diversification of movement hinders drawing a clear pattern of a new hierarchy of political positions. Nevertheless, some political positions are seen as having limited attractiveness (boards of districts), and it could be argued that in regions the balance of power shifted towards self-government (as indicated by the more intensive movement from the positions of voivodes and their deputies towards regional boards than in the opposite direction). Finally, this new hierarchy cannot be produced, as interviews with heads of regional boards showed that their political ambitions are diversified (although a large group of them would prefer if the institutional structure of opportunity enabled them to continue their career in the regional executive).

\section{Acknowledgments}

This research was funded by Project 2013/11/B/HS6/01196 of the National Science Centre, Poland, and is part of a research project entitled Recruitment and Social Background of the Regional Government Elite in the Period 1998-2014. An earlier draft of this work was presented at the 24th World Congress of Political Science (Poznań, 23-28 July 2016).

\section{References}

Almanach Polskiej Władzy 1989-2002 (2002): Warszawa: Centralny Ośrodek Informacji Gospodarczej.

Botella, J., Teruel, J. R., Barberà, O. and Barrio, A. (2010): A new political elite in Western Europe? The political careers of regional prime ministers in newly decentralised countries. French Politics l(8): 42-61.

Błażej, M. (2015): Gospodarka finansowa jednostek samorządu terytorialnego, Studia i analizy statystyczne, Warszawa, Gtówny Urząd Statystyczny. Available at:

http://stat.gov.pl/obszary-tematyczne/rachunki-narodowe/statystyka-sektora-instytucji-rzadowych-i-samorzadowych/gospodarka-finansowa-jednostek-samorzadu-terytorialnego-2014,5,11.html (24 February 2020).

Bober, J., Hausner, J., Izdebski, H., Lachiewicz, W., Mazur, S., Nelicki, A., Nowotarski, B., Puzyna, W., Surówka, K., Zachariasz, I., Zawicki, M. (2013): Narastające dysfunkcje, zasadnicze dylematy, konieczne działania. Raport o stanie samorządności w Polsce, Kraków, Uniwersytet Ekonomiczny w Krakowie. 
Borchert, J. (2011): Individual Ambition and Institutional Opportunity: A Conceptual Approach to Political Careers in Multi-level Systems. Regional \& Federal Studies 21\(2): 117-140.

Borchert, J., Stolz, K. (2011a): Introduction: Political Careers in Multi-level Systems. Regional \& Federal Studies 21(2): 107-115.

Borchert, J., Stolz, K. (2011b): German Political Careers: The State Level as an Arena in its Own Right? Regional \& Federal Studies 21(2): 205-222.

Docherty, D. (2011): The Canadian Political Career Structure: From Stability to Free Agency. Regional \& Federal Studies 21(2): 185-203.

Dodeigne, J. (2018) Who governs? The disputed effects of regionalism on legislative career orientation in multilevel systems. West European Politics 41 (3): 728-753.

Fischer, J., Stolz, K. (2010): Patterns of ministerial careers across territorial levels in Germany, Paper prepared for the 82nd Annual Conference of the Canadian Political Science Association June 1-3, Concordia University, Montreal.

Drzonek, M. (2016): Wielokadencyjność bez afiliacji partyjnej? Spostrzeżenia po reelekcjach 'wiecznych prezydentów' w 2014. Przegląd Politologiczny 1: 81-89.

Grimaldi, S., Vercesi, M. (2018): Political careers in multi-level systems: Regional chief executives in Italy, 1970-2015, Regional and federal studies 28 (2): 125-149.

Hooghe, L., Marks, G., Schakel, A. (2010): The Rise of Regional Authority: A Comparative Study of 42 Democracies, London and New York: Taylor \& Francis.

Ile zarabiają marszatkowie województw? Available at: http://www.regiopraca.pl/portal/rynek-pracy/zarobki/ile-zarabiaja-marszalkowie-wojewodztw (24 February 2020).

Ignasiak, R. et al. (1993): Kto jest kim w polityce polskiej, Warszawa: Polska Agencja Informacyjna. Izdebski, H. (1996): Historia administracji, Warszawa: Liber.

Jäckle, S. (2013): Ministerial turnover in the German Länder (1991-2010). Zeitschrift für Vergleichende Politikwissenschaft 7(1): 27-48.

Koalicja PO-PSL będzie rządzić w 15 sejmikach wojewódzkich https://www.tvn24.pl/wiadomosci-z-kraju,3/koalicja-po-psl-bedzie-rzadzic-w-15-sejmikach-wojewodzkich,492507.html

Lewis, P. (2009): Political Authority and Party Secretaries in Poland, 1975-1986, Cambridge, Part of Cambridge Russian, Soviet and Post-Soviet Studies.

Loughlin, J. (2001): Subnational Democracy in the European Union: Challenges and Opportunities: Challenges and Opportunities, Oxford: OUP.

Machelski, Z. (2008): Lokalny wymiar opozycji i koalicji partyjnych. In: Polityka lokalna. Właściwości, determinanty, podmioty, ed. E. Ganowicz, L. Rubisz, Toruń: Wydawnictwo Adam Marszałek.

Majcherkiewicz, T. (forthcoming 2020): Polityka i politycy regionalni w systemie wielopoziomowym, Uniwersytet Pedagogiczny w Krakowie.

Majcherkiewicz, T. (2018): Tworzenie koalicji regionalnych a ewolucja systemu wielopoziomowego w opinii marszałków województw od I do V kadencji. Athenaeum. Polskie Studia Politologiczne 57: 54-77. 
Majcherkiewicz, T. (2016): Wzory tworzenia wojewódzkich koalicji samorządowych a skład polityczny zarządów województw w latach 1998-2014, Studia Polityczne 2 (42): 113-144.

Pallarés, F., Keating, M. (2003): Multi-Level Electoral Competition. Regional Elections and Party Systems in Spain. European Urban and Regional Studies 10(3): 239-255.

Piasecki, A. (2009): Samorząd terytorialny i wspólnoty lokalne, Wydawnictwo Naukowe PWN S.A.

Schakel, A., Dandoy, R. (2013): Introduction: Territoriality of the Vote: A Framework for Analysis. In: Dandoy R. and Schakel A., Regional and National Elections in Western Europe: Territoriality of the Vote in Thirteen Countries, Palgrave Macmillan.

Skład Rady Ministrów, Biuletyn Informacji Publicznej, Available at: https://bip.kprm.gov.pl/ kpr/bip-rady-ministrow/sklad-rady-ministrow/4574,Sklad-Rady-Ministrow.html) (24 February 2020).

Stolz, K. (2005): Bringing Politicians back in: Regional Democracy and Political Careers, Paper prepared for ECPR Joint Sessions of Workshops, Granada, 14-19 April, 2005 Workshop 30 „Patterns of Regional Democracies: Institution Building and Policy Performance in European Autonomous Regions".

Stolz, K. (2003): Moving up, moving down: political careers across territorial levels, European Journal of Political Research, vol. 42.

Stolz, K. (2011): The Regionalization of Political Careers in Spain and the UK, Regional \& Federal Studies 21(2): 223-243.

Stolz, K., Fischer, J. (2014): Post-Cabinet Careers of Regional Ministers in Germany, 1990-2011, German Politics 23(3): 157-173.

Swianiewicz (2014): The Unfinished Story of the Ugly Duckling: Polish Regions under the Realm of Europeanization. Croatian and Comparative Public Administration. 355-379.

Tusk: jest porozumienie PO-PSL o koalicji w sejmikach. Available at: https://wiadomosci.wp.pl/ tusk-jest-porozumienie-po-psl-o-koalicji-w-sejmikach-6082117185360513a (24 February 2020).

Ujdak, M. (1996): Samorząd. In: Serafin F., Województwo śląskie (1922-1939). Zarys monograficzny, Katowice: Wydawnictwo Uniwersytetu Śląskiego.

Ustawa z dnia 5 czerwca 1998 r. o samorządzie województwa. Dz. U. 1998 no 91 poz. 576.

Trochymiak, M. (2017): Wzory działania administracji publicznej w Polsce i ich przekształcenia. In: Państwo w praktyce, style działania ed J. Raciborski, Kraków: Nomos.

Vanlangenakker, I., Maddens, B., Put, G.-J. (2013): Career Patterns in Multilevel States: An Analysis of the Belgian Regions, Regional Studies 47(3): 356-367.

Weber M. (2011): Politics as a Vocation 1-27. Available at: http://anthropos-lab.net/wp/wp-content/uploads/2011/12/Weber-Politics-as-a-Vocation.pdf (24 February 2020).

Wykaz 2000 osób sprawujących władzę w Rzeczypospolitej Polskiej (1994) Warszawa: Wydawnictwo Wiejska.

Wykaz 2000 osób sprawujących władzę w Rzeczypospolitej Polskiej (1997): Warszawa: Presspublica. 
Regional Self-government websites:

1. Urząd Marszałkowski Województwa Dolnośląskiego: http://www.umwd.dolnyslask.pl/

2. Urząd Marszałkowski Województwa Kujawsko-pomorskiego: http://www.kujawsko-pomorskie. $\mathrm{pl} /$

3. Urząd Marszałkowski Województwa Lubelskiego: http://www.lubelskie.pl/

4. Urząd Marszałkowski Województwa Lubuskiego: http://lubuskie.pl/

5. Województwo Łódzkie - Urząd Marszałkowski: http://www.lodzkie.pl/wps/wcm/connect/ lodzkie/lodzkie/

6. Małopolska - Urząd Marszałkowski Województwa; https://www.malopolska.pl

7. Samorząd Województwa Mazowieckiego: http://www.mazovia.pl/,

8. Samorząd Województwa Opolskiego: http://opolskie.pl/serwis/

9.Urząd Marszałkowski Województwa Podkarpackiego: http://www.umwp.podkarpackie.pl/

10. Wrota Podlasia; http://www.wrotapodlasia.pl/pl/adm/samorzad_woj

11.Pomorskie.eu. Portal Urzędu Marszałkowskiego Województwa Pomorskiego; http://urzad. pomorskie.eu/pl

12. Urząd Marszałkowski Województwa Śląskiego; http://www.slaskie.pl/

13. Urząd Marszałkowski Województwa Świętokrzyskiego: http://www.sejmik.kielce.pl/ index,1.html

14. Urząd Marszałkowski Województwa Warmińsko-Mazurskiego; http://wrota.warmia. mazury.pl/

15. Samorząd Województwa Wielkopolskiego: http://www.umww.pl/

16. Urząd Marszałkowski Województwa Zachodniopomorskiego: http://www.wzp.pl/

Tatiana Majcherkiewicz is an Assistant Professor at the Faculty of Sociology and Philosophy, The Cracow Pedagogical University, Poland. Her research encompasses regional and national elites, political careers, regional coalitions and civil service corps. She recently received a grant from the Polish National Centre of Science for a study entitled: The recruitment and composition of the Polish regional self-governing elite in the period 1998-2014. Her international experience is extensive and includes works and research on regional elites and the EU's enlargement and politico-administrative relations. She is an author of about forty academic articles, written in Polish and English. In 2011 she published a book: An Elite in Transition: An Analysis of the Higher Administration of the Region of Upper Silesia, Poland, AP Lambert Academic Publishing. E-mail: tmajcherkiewicz@gmail.com 